\title{
UJI AKTIVITAS ANTIOKSIDAN TERHADAP DPPH DAN IDENTIFIKASI GOLONGAN SENYAWA AKTIF EKSTRAK KASAR MIKROALGA Chlorella sp. HASIL KULTIVASI DALAM MEDIUM EKSTRAK TAUGE
}

\author{
Siti Khairul Bariyyah, A. Ghanaim Fasya, Munirul Abidin, A. Hanapi
}

Jurusan Kimia, Fakultas Sains dan Teknologi, UIN Maulana Malik Ibrahim Malang

\begin{abstract}
Chlorella $s p$. is one of the low-level plants that have the potential to be utilized, as stated in al Quran surah asy Syu'ara: 7. Chlorella $s p$. is one species of microalgae containing antioxidant compound, such as flavonoid, tanin, phenolic compound, terpenoid, chlorophyll and karotenoid. Purpose this research was to determine potential antioxidant activity and active compound of Chlorella sp.

Chlorella $s p$. was cultivated in Tauge Extract Medium (TEM) $4 \%$ and harvesting at $10^{\text {th }}$ day. Extraction of Chlorella sp. was estimated by maceration method using two variationsolvent, methanol and ethyl acetate. Antioxidant activity of crude extract Chlorella $s p$. wasestimated by DPPH assay with spectrofotometryUV-Vis. Identification of active compound was estimated by phytochemical reagent assay, as alkaloid, flavonoid, steroid, triterpenoid, tanin, and ascorbic acid.

The result showed that the highest number of cells $\left(4,6 \times 10^{5}\right.$ cell $\left./ \mathrm{mL}\right)$ when Chlorella $s p$. cultivation in TEM occured at $10^{\text {th }}$ day. The rendemen of methanol and ethyl acetate extract of Chlorellasp. as follows 7,001\% and 3,673\%. $\mathrm{EC}_{50}$ value of methanol and ethyl acetate extract Chlorellasp. were 18,610 ppm and 27,320 ppm. The identification result of active compound of crude extract Chlorellasp. showed that methanol extract contains steroid, tannin, and ascorbic acid, while ethyl acetate extract contains tannin and ascorbic acid.
\end{abstract}

Keywords : Chlorella sp., Tauge Extract Medium, Antioxidant, DPPH

\begin{abstract}
ABSTRAK
Chlorella sp. merupakan salah satu tumbuhan tingkat rendah yang mempunyai potensi untuk dimanfaatkan, sebagaimana Firman Allah Swt. dalam al-Quran surat asy Syu'ara ayat 7. Chlorella sp. termasuk dalam spesies mikroalga dari kelompok Chlorophyta yang mengandung senyawa yang berpotensi sebagai antioksidan seperti flavonoid, tanin, senyawa fenolik, terpenoid, klorofil dan karotenoid. Tujuan dari penelitian ini adalah untuk mengetahui potensi aktivitas antioksidan dan golongan senyawa aktif dari Chlorella sp. yang ditumbuhkan dalam Medium Ekstrak Tauge (MET).

Chlorella sp. dikultivasi dalam MET $4 \%$ dan pemanenan dilakukan pada hari ke-10. Ekstraksi Chlorella sp. dilakukan dengan metode maserasi menggunakan dua variasi pelarut yaitu metanol dan etil asetat. Aktivitas antioksidan ekstrak kasar Chlorella sp. dilakukan dengan uji DPPH secara spektrofotometri sinar tampak. Identifikasi golongan senyawa aktif dilakukan dengan menggunakan uji reagen secara kualitatif yang meliputi alkaloid, flavonoid, steroid, triterpenoid, tanin, dan asam askorbat.

Hasil penelitian menunjukkan bahwa kerapatan sel tertinggi $(4,6 \times 105 \mathrm{sel} / \mathrm{mL})$ saat kultivasi Chlorella sp. dalam MET terjadi pada hari ke-10. Rendemen dari ekstrak metanol dan ekstrak etil asetat Chlorellasp. berturut-turut adalah 7,001 \% dan 3,673\%. Ekstrak metanol Chlorella sp. mempunyai aktivitas antioksidan yang kuat dengan nilai EC50 sebesar 18,610 ppm, begitu juga dengan ekstrak etil asetat yang mempuyai nilai EC50 sebesar 27,320 ppm. Hasil identifikasi golongan senyawa aktif yang terkandung dalam ekstrak kasar Chlorella sp. menunjukkan bahwa ekstrak metanol mengandung steroid, tanin dan asam askorbat, sedangkan ekstrak etil asetat mengandung tanin dan asam askorbat.
\end{abstract}

Kata kunci : Chlorella sp., MET, Antioksidan, DPPH

\section{PENDAHULUAN}

Chlorella sp. merupakan tumbuhan ganggang hijau bersel tunggal, hidup menyendiri atau berkelompok, tidak mempunyai batang, akar, dan daun sebenarnya. Chlorella sp. tumbuh di air tawar, air payau, dan air asin. Beberapa keunggulan mikroalga Chlorella sp., 
diantaranya berkembang biak dengan cepat, mudah dalam membudidayakannya (Sidabutar, 1999) karena hidupnya tidak tergantung musim, tidak memerlukan tempat yang luas dan tidak memerlukan waktu yang lama untuk memanennya (Borowitzka, 1988), keseluruhan organnya dapat dimanfaatkan, mengandung senyawa pemacu pertumbuhan. Selain itu, Chlorella sp. mengandung berbagai nutrien seperti protein, karbohidrat, asam lemak tak jenuh, vitamin, enzim (Kawaroe, 2008), klorofil a, klorofil b, serta karotenoid. Klorofil dan karotenoid ini dapat berfungsi sebagai antioksidan.

Antioksidan merupakan senyawa yang dapat menghambat reaksi oksidasi, dengan mengikat radikal bebas dan molekul yang sangat reaktif (Winarsi, 2007). Keberadaan antioksidan dapat melindungi tubuh dari berbagai penyakit degeneratif dan kanker, serta membantu menekan proses penuaan/ antiaging (Tapan, 2005). Saat ini antioksidan yang umum digunakan merupakan antioksidan sintetik diantaranya Butylated hydroxyanisole (BHA), Butylated hydroxytoluene (BHT), Propylgallate (PG) dan Tert-Butylhydroquinone (TBHQ) (Sherwin, 1990). Akan tetapi, senyawa tersebut dicurigai dapat menyebabkan keracunan dan efek karsinogenik (Grillo dan Gulout, 1995; Safer an Nughamish, 1999; Shanab, 2007). Oleh karena itu, pengembangan serta pemanfaatan antioksidan yang lebih efektif dan berasal dari alam penting untuk dilakukan (Oktay, et al., 2003).

Pengujian aktivitas antioksidan mikroalga Chlorella $s p$. yaitu pada ekstrak biomassa. Oleh karena itu, Chlorella sp. dikultivasi terlebih dahulu dalam media kultur. Media yang digunakan dalam penelitian ini adalah Medium Ekstrak Tauge (MET). MET ini merupakan salah satu media alami untuk pertumbuhan mikroalga. Tauge kacang hijau merupakan jenis sayuran yang umum dikonsumsi, mudah diperoleh, ekonomis, dan tidak menghasilkan senyawa yang berefek toksik. Media perlakuan MET mengandung nutrient organik seperti karbohidrat, protein, vitamin dan lemak yang dibutuhkan sebagai sumber energi bagi pertumbuhan mikroalga. Selain itu, media perlakuan MET ini juga mengandung makronutrient anorganik seperti $\mathrm{K}, \mathrm{P}, \mathrm{Ca}$, $\mathrm{Mg}$, dan $\mathrm{Na}$ yang dibutuhkan oleh sel mikroba sebagai komponen penyusun sel, sedangkan mikronutrien seperti Fe, Zn, Mn, dan $\mathrm{Cu}$ dibutuhkan oleh sel sebagai kofaktor enzim dan sebagai komponen pembentuk klorofil (Richmond, 2006). Dilaporkan bahwa senyawa-senyawa dalam media kultur juga akan mengefektifkan fotosintesis pada mikroalga. Fotosintesis yang berlangsung efektif akan mempengaruhi produk yang dihasilkan (Wulandari, dkk., 2010). Selain itu, setiap jenis media kultur memberikan pengaruh berbeda terhadap kualitas kandungan mikroalga (Carolina, 1995).

\section{METODE PENELITIAN Lokasi dan Waktu Penelitian}

Penelitian ini dilaksakan di Laboratorium Kimia Organik, Laboratorium Bioteknologi Jurusan Kimia dan Laboratorium Ekologi Jurusan Biologi Universitas Islam Negeri (UIN) Maulana Malik Ibrahim Malang pada bulan Maret Mei 2013.

\section{Alat}

Seperangkat alat gelas, cawan porselen, shaker, oven, desikator, rotary evaporator vacuum, kuvet, inkubator, pipet tetes, aluminium foil, neraca analitik, sentrifuse, spektronik 20+, dan spektofotometer UV-Vis Varian Carry.

\section{Bahan}

Isolat mikroalga Chlorella sp. dari Laboratorium Ekologi Universitas Maulana Malik Ibrahim Malang. Bahan-bahan lain yang digunakan adalah metanol p.a., etil asetat p.a., tauge (kacang hijau), akuades, larutan DPPH, kloroform, anhidrida asetat, asam sulfat pekat, serbuk $\mathrm{Mg}, \mathrm{HCl} 37 \%$, $\mathrm{HCl} 2 \%$, reagen Dragendorff, reagen Mayer, $\mathrm{FeCl}_{3} 1 \%$, larutan gelatin, kalium permanganat, vitamin $\mathrm{C}$, dan BHT. 


\section{Metode Penelitian}

\section{A. Kultivasi Mikroalga Chlorella sp. \\ 1. Sterilisasi Alat}

Ditutup alat-alat yang akan disterilkan dengan alumunium foil. Dimasukkan ke dalam autoklaf dan diatur pada suhu 121 oC dengan tekanan 15 psi (per square inchi). Sterilisasi dilakukan untuk alat selama 30 menit (Hidayat, 2009).

\section{Pembuatan Medium Ekstrak Tauge}

Pembuatan medium ekstrak tauge diawali dengan pembuatan larutan stok MET yaitu 100 gram tauge direbus dalam $500 \mathrm{~mL}$ akuades yang mendidih selama 1 jam hingga volume ekstrak $200 \mathrm{~mL}$. Medium ekstrak tauge dibuat dengan cara melarutkan ekstrak tauge ke dalam akuades dengan masing-masing konsentrasi $4 \%$ (Prihantini, dkk., 2005).

\section{Kultivasi Chlorella sp. dalam Media \\ Ekstrak Tauge}

Sebanyak $100 \mathrm{ml}$ isolat Chlorella sp. diinokulasikan ke dalam masing-masing $600 \mathrm{~mL}$ MET dalam erlenmeyer $1000 \mathrm{~mL}$ yang ditempatkan pada rak kultur yang telah dilengkapi dengan pencahayaan menggunakan lampu TL 36 watt (intensitas cahaya $1000-4000$ lux) dan fotoperiodisitas 14 jam terang dan 10 jam gelap selama 10 hari (Prihantini, dkk., 2005).

\section{Pemanenan Biomassa Chlorella sp.}

Media kultur Chlorella sp. disentrifuse selama 15 menit dengan kecepatan $3000 \mathrm{rpm}$. Biomassa Chlorella $s p$. dipisahkan dari supernatannya.

\section{B. Penentuan Kadar Air}

Cawan yang akan digunakan dipanaskan dahulu dalam oven pada suhu 100-105 ${ }^{\circ} \mathrm{C}$ selama 15 menit, kemudian cawan disimpan dalam desikator 10 menit, selanjutnya ditimbang dan dilakukan perlakuan yang sama hingga diperoleh berat cawan yang konstan. Biomassa Chlorella sp. ditimbang $1 \mathrm{mg}$ kemudian dimasukkan ke dalam cawan dan dikeringkan di dalam oven pada suhu $100-105^{\circ} \mathrm{C}$ selama 30 menit, kemudian dimasukkan dalam desikator dan ditimbang. Selanjutnya, dipanaskan kembali dalam oven 30 menit, didinginkan dalam desikator dan ditimbang kembali hingga berat konstan. Kadar air dihitung menggunakan rumus berikut :

Kadar air $=\frac{(b-c)}{b-a} \times 100 \%$

Dimana :

$\mathrm{a}=$ bobot cawan kosong

$\mathrm{b}=$ bobot sampel + cawan sebelum dipanaskan

$\mathrm{c}=$ bobot cawan + sampel setelah dipanaskan

\section{Preparasi Sampel}

Sampel biomassa Chlorella sp. basah diambil seluruhnya kemudian dikeringanginkan pada suhu ruang selama 12 jam. Selanjutnya dilakukan ekstraksi pada sampel biomassa kering yang diperoleh.

\section{Ekstraksi Senyawa Aktif Mikroalga} Chlorella sp.

Biomassa Chlorella sp. kering diambil 50 gram kemudian dimaserasi masing-masing dengan pelarut metanol dan etil asetat sebanyak $250 \mathrm{~mL}$ selama 24 jam dengan dishaker selama 5 jam. Maserasi dilakukan tiga kali. Setelah itu dipisahkan antara filtrat dengan residu menggunakan corong buchner. Filtrat yang diperoleh dipekatkan dengan rotary evaporator vacuum hingga diperoleh ekstrak pekat metanol dan etil asetat.

E. Uji Aktivitas Antioksidan dengan DPPH (1,1-diphenyl-2-picrylhydrazyl)

\section{Penentuan Panjang Gelombang Maksimum}

Larutan DPPH 0,5 $\mathrm{mM}$ sebanyak 5 $\mathrm{mL}$ dimasukkan dalam kuvet hingga penuh. Dicari $\lambda_{\text {maks }}$ larutan dan dicatat hasil pengukuran $\lambda_{\text {maks }}$ untuk digunakan pada tahap selanjutnya (Hanani, dkk., 2005).

2. Penentuan Waktu Kestabilan

Pengukuran Antioksidan 
Larutan ekstrak 30 ppm dipipet sebanyak 6,75 mL. Ditambahkan larutan DPPH $0,5 \mathrm{mM}$ sebanyak 2,25 $\mathrm{mL}$, kemudian dicari waktu kestabilan tanpa inkubasi dan setelah inkubasi pada suhu 37 ${ }^{\circ} \mathrm{C}$ dan rentangan waktu $5-100$ menit dengan interval 5 menit. Sampel diukur pada $\lambda_{\text {maks }}$ yang telah diketahui pada tahap sebelumnya.

\section{Pengukuran Potensi Antioksidan Pada}

\section{Sampel}

Sampel ekstrak dilarutkan dalam pelarutnya dengan konsentrasi 5, 10, 15, 20, 25, dan $30 \mathrm{ppm}$. Ekstrak masing-masing konsentrasi dipipet $6,75 \mathrm{~mL}$ dan ditambahkan 2,25 $\mathrm{mL}$ DPPH $0,5 \mathrm{mM}$ kemudian diinkubasi dengan suhu $37{ }^{\circ} \mathrm{C}$ pada waktu kestabilan yang diperoleh pada tahap sebelumnya, kemudian diukur absorbansinya menggunakan spektrofotometer UV-Vis pada panjang gelombang 518,0 nm. Data absorbansinya yang diperoleh dari tiap konsentrasi masing-masing ekstrak dihitung nilai persen (\%) aktivitas antioksidannya (Arindah, 2010):

$$
\begin{aligned}
& \text { Aktivitas } \\
& \text { antioksidan }
\end{aligned}=\left(\frac{\text { A kontrol-A sampel }}{\text { Akontrol }}\right) \times 100 \%
$$

Selanjutnya, dihitung nilai $\mathrm{EC}_{50}$ nya dengan memperoleh persamaan regresi menggunakan program "GraphPad prism5 software, Regression for analyzing doseresponse data".

Kontrol yang digunakan yaitu larutan DPPH 0,5 mM dalam metanol p.a.

Pembanding BHT dan asam askorbat (Vitamin C) diperlakukan seperti sampel.

\section{F. Identifikasi Golongan Senyawa Aktif Secara Kualitatif}

\section{Uji Triterpenoid dan Steroid}

Ekstrak kasar diambil dan dilarutkan dengan kloroform sebanyak $0,5 \mathrm{~mL}$, lalu ditambah dengan $0,5 \mathrm{~mL}$ anhidrida asetat. Selanjutnya ditambah dengan $1-2 \mathrm{~mL}$ $\mathrm{H}_{2} \mathrm{SO}_{4}$ pekat melalui dinding tabung tersebut. Warna hijau kebiruan menunjukkan adanya steroid, jika berupa cincin kecoklatan atau violet pada perbatasan dua pelarut menunjukkan adanya triterpenoid.

\section{Uji Flavonoid}

Ekstrak dilarutkan dalam $1-2 \mathrm{~mL}$ metanol panas $50 \%$, kemudian ditambah logam $\mathrm{Mg}$ dan 0,5 $\mathrm{mL} \mathrm{HCl}$ pekat. Senyawa flavonoid akan menimbulkan warna merah atau jingga.

\section{Uji Alkaloid}

Ekstrak kasar ditambah $0,5 \mathrm{~mL} \mathrm{HCl}$ $2 \%$, selanjutnya larutan dibagi dalam dua tabung. Tabung I ditambahkan $2-3$ tetes reagen Dragendorff, tabung II ditambahkan $2-3$ tetes reagen Mayer. Jika tabung I terbentuk endapan jingga dan pada tabung II terbentuk endapan kekuning-kuningan menunjukkan adanya alkaloid.

\section{Uji Tanin}

\section{- Uji dengan $\mathrm{FeCl}_{3}$}

Ekstrak ditambahkan dengan $2-3$ tetes larutan $\mathrm{FeCl}_{3} 1 \%$. Jika larutan menghasilkan warna hijau kehitaman atau biru tua, maka mengandung tanin.

\section{- Uji dengan Larutan Gelatin}

Ekstrak ditambah dengan larutan gelatin. Jika terbentuk endapan putih, menunjukkan adanya tanin.

\section{Uji Asam Askorbat}

Masing-masing ekstrak dilarutkan dalam akuades kemudian ditambahkan larutan $\mathrm{KMnO}_{4}$ 0,1 \%. Jika terbentuk warna cokelat maka menunjukkan adanya asam askorbat.

\section{G. Analisis Data}

Analisis data dilakukan dengan menghitung persen (\%) aktivitas antioksidan yang diperoleh dari data absorbansi kemudian dilakukan perhitungan nilai $\mathrm{EC}_{50}$ dengan menggunakan persamaan regresi yang menyatakan hubungan antara konsentrasi ekstrak (x) dengan persen (\%) aktivitas antioksidan (y). Sampel yang mempunyai nilai $\mathrm{EC}_{50}$ terendah menunjukkan bahwa sampel tersebut memiliki kemampuan sebagai antioksidan yang tinggi. 


\section{HASIL DAN PEMBAHASAN}

\section{A. Kultivasi Mikroalga Chlorella sp.}

Kultivasi Chlorella sp. dilakukan dalam Medium Ekstrak Tauge (MET) menggunakan erlenmeyer $1000 \mathrm{~mL}$. MET merupakan salah satu sumber media alami yang dapat digunakan untuk media pertumbuhan mikroalga (Prihantini, dkk., 2005). MET mengandung unsur makro dan mikro, vitamin, mineral serta asam amino yang dibutuhkan bagi pertumbuhan mikroalga. Unsur hara yang terkandung dalam MET seperti $\mathrm{K}, \mathrm{P}, \mathrm{Fe}, \mathrm{Na}$, dan $\mathrm{K}$, sedangkan vitamin yang terkandung dalam media tersebut diantaranya karoten, thiamin, riboflavin, niasin, dan vitamin $\mathrm{C}$ (Persagi, 2009).

Chlorella sp. dikultur dalam MET selama 10 hari dengan fotoperiodisitas 14 jam terang dan 10 jam gelap. Cahaya mempunyai peranan yaitu sebagai sumber energi dalam proses fotosintesis. Penyinaran dengan lampu TL selama kultur digunakan sebagai pengganti cahaya matahari agar sel Chlorella sp. dapat melakukan proses fotosintesis.

Temperatur selama kultivasi Chlorella sp. menggunakan temperatur ruang (biasanya berkisar antara temperatur $25-30{ }^{\circ} \mathrm{C}$ ). Kondisi temperatur tersebut merupakan kisaran temperatur yang baik untuk pertumbuhan mikroalga termasuk Chlorella sp. karena untuk pertumbuhan mikroalga yang optimal digunakan temperatur $15-30{ }^{\circ} \mathrm{C}$ (De La Nouve dan De Pauw, 1988).

Derajat keasaman $(\mathrm{pH})$ pada kultur Chlorella sp. selama kultivasi berkisar 7 7,2 . Kisaran $\mathrm{pH}$ ini berada pada kisaran $\mathrm{pH}$ yang sesuai untuk pertumbuhan mikroalga yaitu 4,5 - 9,3 (Prihantini, dkk., 2005).

Selama kultivasi terjadi perubahan warna kultur pada media perlakuan yang semula berwarna hijau kekuningan menjadi hijau tua seperti pada Gambar 1. Warna hijau dari kelima media relatif sama. Perubahan warna kultur ini diasumsikan juga diikuti dengan peningkatan kepadatan sel Chlorella sp. yang menandakan terjadinya pemanfaatan nutrien (unsur hara) yang terkandung dalam MET oleh sel-sel Chlorella sp. Begitu juga kesesuaian faktor cahaya, temperatur, dan $\mathrm{pH}$ yang digunakan mendukung penyerapan nutrien oleh sel-sel Chlorella sp.

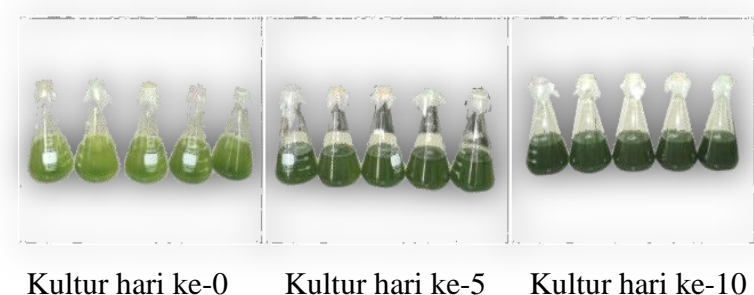
Gambar 1. Warna kultur Chlorella sp. pada hari berbeda

Pertumbuhan mikroalga pada kultur juga ditandai dengan bertambah besarnya ukuran sel atau bertambah banyaknya jumlah sel. Pertumbuhan Chlorella sp. yang dikultivasi dalam MET pada penelitian ini memiliki pola pertumbuhan yang dimulai dari fase eksponensial, fase stasioner, dan fase kematian. Fase eksponensial dimulai dari hari ke-0 sampai hari ke-8, fase stasioner terjadi pada hari ke-8 sampai hari ke-11 dan fase kematian setelah hari ke-11 sampai hari ke-15. Pola pertumbuhan Chlorella sp. tidak mengalami fase lag. Hal ini terjadi karena Chlorella sp. yang diinokulasikan tersebut diambil dari fase eksponensial sehingga tidak mengalami fase lag. Salah satu faktor yang menentukan lamanya fase adaptasi adalah umur kultur yang digunakan sebagai inokulum. Fase adaptasi akan menjadi lebih singkat atau bahkan tidak terlihat apabila sel-sel yang diinokulasikan berasal dari kultur yang berada dalam fase eksponensial. Fase adaptasi tidak terlihat secara jelas pada media perlakuan kemungkinan juga disebabkan sel-sel yang diinokulasikan cepat beradaptasi terhadap media kultur yang baru, mampu tumbuh dan membelah dengan cepat (Prihantini, dkk., 2005).

\section{B. Pemanenan Mikroalga Chlorella sp.}

Pemanenan Chlorella sp. dilakukan pada fase stasioner. Fase stasioner 
merupakan tahap pertumbuhan yang konstan dimana laju reproduksi sama dengan laju kematian. Meskipun pada fase stasioner nutrien semakin berkurang, tetapi pembelahan sel masih dapat berlangsung. Hal ini disebabkan sel memiliki cadangan energi sehingga masih dapat menggunakan komponen tersebut untuk melakukan pertumbuhan dan mempertahankannya meski sangat rendah (Schlegel, 1994). Pada fase stasioner juga terjadi metabolisme sekunder yang merupakan keseluruhan proses sintesis dan perombakan produk metabolit primer (Herbert, 1995). Selain itu, terjadi penumpukan produk beracun dan kehabisan nutrien, serta menghasilkan komponen-komponen (metabolit sekunder) yang berfungsi untuk pertahanan hidup. Contoh produk senyawa metabolit sekunder seperti senyawa fenol, alkaloid, triterpenoid (Yudha, 2008).

Pemanenan Chlorella sp. dilakukan pada fase stasioner yaitu pada hari ke-10. Hal ini karena pada hari tersebut, pertumbuhan Chlorella sp. mencapai kepadatan sel tertinggi yang ditandai dengan kultur yang berwarna hijau tua dengan jumlah sel 4,6 x $10^{6} \mathrm{sel} / \mathrm{mL}$. Proses pemanenan Chlorella sp. dilakukan dengan cara mengumpulkan biomassa dan filtrat dalam wadah botol. Filtrat dan biomassa dari hasil pemanenan dipisahkan menggunakan sentrifuse dengan kecepatan $3000 \mathrm{rpm}$ selama 15 menit. Teknik pemisahan biomassa dan filtrat dengan menggunakan sentrifuse merupakan salah satu cara yang efisien (Volshak, 1990).

\section{Analisis Kadar Air}

Penentuan kadar air dilakukan dengan menguapkan sampel dalam oven pada suhu $100-105^{\circ} \mathrm{C}$. Kadar air dari biomassa Chlorella sp. ditunjukkan pada Tabel 1.

Tabel 1. Kadar air biomassa Chlorella sp.

\begin{tabular}{rc}
\hline Biomassa & Kadar Air (\%) \\
\hline Basah & 93,046 \\
Kering & 12,036 \\
\hline
\end{tabular}

\section{Preparasi Sampel}

Preparasi sampel pada mikroalga Chlorella sp. dilakukan dengan cara pengeringan biomassa hasil kultur. Pengeringan biomassa mikroalga Chlorella $s p$. dilakukan dengan cara dikeringanginkan pada suhu ruang selama 12 jam menggunakan kipas angin. Hembusan kipas angin yang dihasilkan kipas angin tidak menimbulkan panas dan dapat membawa uap air yang lebih besar daripada pengeringan AC dan blowerheat, sehingga proses pengeringan berlangsung lebih cepat sebelum terjadinya kerusakan bahan (Sopyan, 2001).

Hasil yang diperoleh dari proses pengeringan ini menunjukkan bahwa dari 400 gram biomassa basah didapatkan biomassa kering sebesar 55 gram, yang berwarna hijau pekat.

\section{E. Ekstraksi Senyawa Aktif Mikroalga Chlorella sp.}

Ekstraksi Chlorella sp. dilakukan dengan metode maserasi menggunakan dua variasi pelarut yang berbeda kepolarannya, yaitu metanol (polar) dan etil asetat (semipolar). Maserasi ini digunakan karena prosesnya mudah, sederhana, dan tidak menggunakan suhu tinggi yang dimungkinkan dapat merusak senyawa aktif pada mikroalga Chlorella sp.

Hasil rendemen ekstrak metanol dan etil asetat ditunjukkan pada Tabel 2.

Tabel 2. Rendemen Ekstrak Chlorella sp.

\begin{tabular}{ccc}
\hline Pelarut & $\begin{array}{c}\text { Rendemen } \\
(\boldsymbol{\%})(\mathbf{b} / \mathbf{b})\end{array}$ & $\begin{array}{c}\text { Warna Ekstrak } \\
\text { Pekat }\end{array}$ \\
\hline Metanol & 7,001 & $\begin{array}{c}\text { Hijau tua pekat } \\
\text { Hijau tua } \\
\text { kecoklatan }\end{array}$ \\
\hline
\end{tabular}

Rendemen ekstrak metanol lebih besar daripada etil asetat, hal ini karena pelarut metanol yang bersifat polar lebih banyak mengekstrak senyawa aktif daripada pelarut etil asetat yang bersifat semipolar. Metanol merupakan pelarut polar yang sering digunakan karena penetrasi ke dalam dinding sel lebih efisien sehingga 
menghasilkan metabolit sekunder lebih banyak. Hal ini menyebabkan maserasi dengan pelarut metanol akan mengahasilkan ekstrak dengan kandungan metabolit sekunder lebih banyak dan beragam.

\section{F. Uji Aktivitas Antioksidan dengan} DPPH (1,1-diphenyl-2-picrylhydrazyl)

\section{Penentuan Panjang Gelombang} Maksimum

Hasil penentuan panjang gelombang $\mathrm{DPPH} \quad 0,5 \quad \mathrm{mM}$ diperoleh panjang gelombang maksimum sebesar 518,0 nm.

\section{Penentuan Waktu Kestabilan Pengukuran Antioksidan}

Pengukuran waktu kestabilan dilakukan untuk mengetahui waktu sampel dan DPPH sudah bereaksi secara stabil yang ditunjukkan dengan tidak adanya lagi penurunan absorbansi. Setiap senyawa memiliki waktu kestabilan yang berbeda untuk dapat bereaksi secara sempurna (Brand dan William, 1995).

Penentuan waktu kestabilan pada ekstrak metanol dan ekstrak etil asetat dilakukan tanpa inkubasi dan dengan inkubasi pada suhu $37{ }^{\circ} \mathrm{C}$ selama $5-100$ menit dengan interval 5 menit. Hasil penentuan waktu kestabilan menunjukkan bahwa sampel yang ditambahkan dengan DPPH dengan inkubasi memiliki nilai absorbansi yang lebih stabil dibandingkan tanpa inkubasi. Grafik penentuan waktu kestabilan ekstrak metanol dan etil asetat setelah ditambah larutan DPPH ditunjukkan pada Gambar 2 dan Gambar 3.

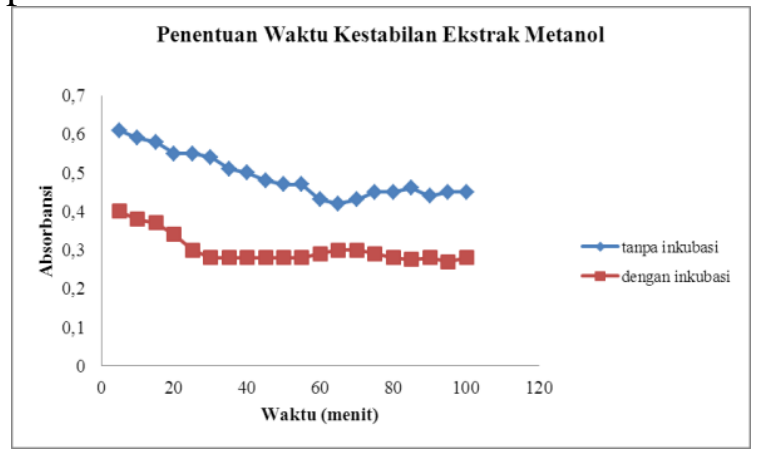

Gambar 2. Penentuan waktu kestabilan ekstrak metanol

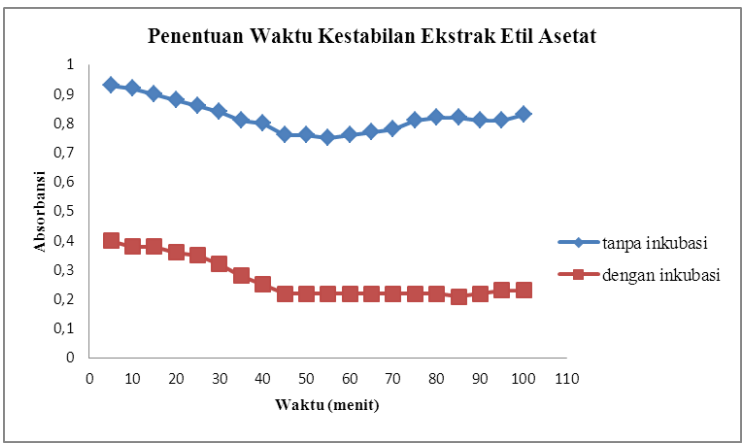

Gambar 3. Penentuan waktu kestabilan ekstrak etil asetat

\section{Pengukuran Potensi Antioksidan pada Mikroalga Chlorella sp.}

Uji kuantitatif potensi antioksidan pada ekstrak Chlorella $s p$. dalam penelitian ini dilakukan dengan uji DPPH secara spekrofotometri sinar tampak. Metode ini didasarkan pada perubahan warna radikal DPPH. Perubahan warna tersebut disebabkan oleh reaksi antara radikal bebas DPPH dengan satu atom hidrogen yang dilepaskan senyawa yang terkandung dalam bahan uji untuk membentuk senyawa 1,1diphenyl-2-picrylhydrazin yang berwarna kuning. Pada metode ini absorbansi yang diukur adalah absorbansi larutan DPPH sisa yang tidak bereaksi dengan senyawa antioksidan (Josephy, 1997).

Pengujian aktivitas antioksidan pada ekstrak metanol dan etil asetat Chlorella sp. yaitu dengan variasi konsentrasi 5, 10, 15, 20, 25, dan $30 \mathrm{ppm}$, selanjutnya diukur serapannya pada panjang gelombang 518,0 $\mathrm{nm}$ dengan waktu kestabilan yang telah didapatkan pada masing-masing ekstrak.

Parameter yang digunakan untuk mengetahui potensi antioksidan dalam ekstrak Chlorella sp. yaitu persen (\%) aktivitas antioksidan dan nilai $\mathrm{EC}_{50}$. $\mathrm{EC}_{50}$ dapat didefinisikan sebagai konsentrasi larutan sampel yang akan menyebabkan reduksi terhadap aktivitas DPPH sebesar 50 $\%$. Semakin kecil nilai $\mathrm{EC}_{50}$ maka aktivitas antioksidannya semakin tinggi (Molyneux, 2004). Data hasil \% aktivitas antioksidan dan nilai $\mathrm{EC}_{50}$ ditunjukkan pada Tabel 3. 
Tabel 3. Persen aktivitas antioksidan dan nilai $\mathrm{EC}_{50}$ ekstrak Chlorella sp. dan pembanding

\begin{tabular}{|c|c|c|c|c|c|c|c|c|}
\hline $\mathbf{N}$ & \multirow{2}{*}{ Sampel } & \multicolumn{6}{|c|}{ \% aktivitas antioksidan } & Nilai \\
\hline $\mathbf{0}$ & & 5 ppm & 10 ppm & 15 ppm & 20 ppm & 25 ppm & 30 ppm & $\mathrm{EC}_{50}(\mathrm{ppm})$ \\
\hline 1 & Ekstrak Metanol & 5,784 & 6,041 & 9,590 & 69,690 & 85,383 & 90,139 & 18,610 \\
\hline 2 & Ekstrak etil asetat & 5,927 & 7,373 & 7,404 & 8,218 & 15,358 & 85,580 & 27,320 \\
\hline 3 & Asam askorbat & 67,620 & 92,744 & 95,056 & 96,190 & 96,744 & 96,795 & 3,527 \\
\hline 4 & BHT & 39,460 & 66,247 & 77,674 & 86,498 & 89,823 & 89,879 & 6,552 \\
\hline
\end{tabular}

Ekstrak mikroalga Chlorella $s p$. fraksi metanol dan etil asetat memiliki potensi antioksidan yang kuat, walaupun lebih rendah jika dibandingkan dengan antioksidan asam askorbat dan BHT.

\section{G. Uji Fitokimia Ekstrak Chlorella sp. dengan Reagen}

Uji fitokimia dilakukan untuk mengetahui kandungan senyawa aktif pada tanaman. Uji fitokimia pada penelitian ini dilakukan terhadap ekstrak metanol dan ekstrak etil asetat Chlorella sp. Hasil uji fitokimia mikroalga Chlorella $s p$. ditunjukkan dalam Tabel 4.

Tabel 4. Hasil pengamatan uji fitokimia ekstrak mikroalga Chlorella sp.

\begin{tabular}{|c|c|c|c|}
\hline \multirow[b]{2}{*}{$\begin{array}{l}\mathrm{N} \\
\mathrm{O}\end{array}$} & \multirow[b]{2}{*}{$\begin{array}{l}\text { Golongan } \\
\text { Senyawa }\end{array}$} & \multicolumn{2}{|c|}{ Hasil Pengujian } \\
\hline & & $\begin{array}{c}\text { Ekstrak } \\
\text { Metanol }\end{array}$ & $\begin{array}{c}\text { Ekstrak } \\
\text { Etil } \\
\text { asetat }\end{array}$ \\
\hline & Alkaloid & - & - \\
\hline 1 & Flavonoid & - & - \\
\hline 2 & Steroid & + & - \\
\hline 3 & Triterpenoid & - & - \\
\hline 4 & Tanin & & \\
\hline 5 & $-\mathrm{FeCl}_{3}$ & - & - \\
\hline & - gelatin & + & + \\
\hline 6 & Asam askorbat & + & + \\
\hline
\end{tabular}

$$
\begin{array}{lll}
\text { Keterangan : tanda }(+): & \text { terkandung } \\
\text { senyawa/warnamuda } & & \\
\text { tanda }(-) \quad: & \text { tidak } & \text { terkandung } \\
\text { senyawa/tidak terbentuk warna } & &
\end{array}
$$

\section{Steroid}

Uji yang digunakan untuk mengidentifikasi adanya golongan senyawa steroid pada ekstrak kasar Chlorella sp. yaitu menggunakan reaksi LiebermannBurchard (anhidrida asetat- $\mathrm{H}_{2} \mathrm{SO}_{4}$ pekat) yang menghasilkan warna hijau biru.
Steroid akan mengalami dehidrasi dengan penambahan asam kuat dan menghasilkan produk oksidasi yang memberikan reaksi warna hijau kebiruan. Hasil identifikasi menunjukkan bahwa ekstrak metanol Chlorella $s p$. mengandung steroid yang ditandai dengan terbentuknya warna hijau kebiruan.

\section{Tanin}

Uji fitokimia adanya senyawa tanin dalam ekstrak Chlorella sp. menggunakan uji dengan $\mathrm{FeCl}_{3}$ dan uji dengan larutan gelatin. Uji fitokimia pertama yaitu menambah ekstrak dengan larutan $\mathrm{FeCl}_{3}$ sebagai reagen, hasil positif ditunjukkan dengan perubahan warna menjadi hijau kehitaman atau biru tua. Sedangkan uji fitokimia kedua yaitu menambahkan gelatin ke dalam ekstrak dan ditunjukkan dengan adanya endapan putih.

Uji fitokimia dengan penambahan $\mathrm{FeCl}_{3}$ menunjukkan hasil negatif karena tidak terbentuk warna hijau kehitaman/biru tua.Uji fitokimia dengan penambahan gelatin menunjukkan hasil positif yang ditunjukkan dengan adanya endapan putih.

Uji fitokimia tanin dengan penambahan $\mathrm{FeCl}_{3}$ menunjukkan hasil negatif sedangkan dengan penambahan gelatin menunjukkan hasil positif. Hal ini diduga karena senyawa tanin yang terkandung dalam ekstrak masih dalam bentuk glikosidanya sehingga sulit berikatan dengan ion logam (mengkelat ion logam). Akan tetapi, dengan penambahan gelatin semua tanin menimbulkan endapan sedikit atau banyak (Harborne, 1987). Hal ini dikarenakan, meskipun masih dalam bentuk glikosidanya, tanin masih mampu 
untuk berinteraksi dengan gelatin melalui ikatan hidrogen.

\section{Asam Askorbat}

Ekstrak metanol dan ekstrak etil asetat positif mengandung asam askorbat yang ditunjukkan dengan terbentuknya warna coklat. Hal ini didukung bahwa asam askorbat bersifat polar sehingga akan larut dalam senyawa polar maupun semipolar.

\section{KESIMPULAN}

Aktivitas antioksidan ekstrak Chlorella sp. terhadap DPPH (1,1-diphenyl2-picrylhydrazyl) ditunjukkan dengan nilai $\mathrm{EC}_{50}$. Nilai $\mathrm{EC}_{50}$ dari ekstrak metanol dan ekstrak etil asetat berturut-turut yaitu 18,610 ppm dan 27,320 ppm. Aktivitas antioksidan Chlorella sp. tergolong kuat karena mempunyai nilai $\mathrm{EC}_{50}$ kurang dari $50 \mathrm{ppm}$.

Hasil identifikasi golongan senyawa dalam ekstrak kasar mikroalga Chlorella $s p$. dengan pelarut metanol dan etil asetat menunjukkan bahwa ekstrak metanol mengandung senyawa steroid, tanin, dan asam askorbat, sedangkan ekstrak etil asetat mengandung tanin dan asam askorbat.

\section{DAFTAR PUSTAKA}

Sidabutar, E.A.. 1999. Pengaruh Medium Pertumbuhan Mikroalga Chlorella $s p$. terhadap Aktivitas Senyawa Pemacu Pertumbuhan yang Dihasilkan. Skripsi Tidak Diterbitkan. Institut Pertanian Bogor.

Borowitzka, M. A. dan Lesley, J. B. 1988. Microalgae Biotechnology. London: Cambridge University Press.

Kawaroe, M. 2008. Mikroalga sebagai Bahan Baku Biofuel. Surfactant and Bioenergy Research Centre, Lembaga Pengabdian Pada Masyarakat, Institut Pertanian Bogor.

Winarsi, H. 2007. Antioksidan Alami dan Radikal Bebas. Yogyakarta: Penerbit Kanisius.

Tapan E.. 2005. Kanker, Antioksidan, dan Terapi Komplementer. Jakarta: PT Gramedia.
Sherwin, F.R., 1990. Antioxidant. In: Food Additive (ed. Branen R). New York: Marcel Dekker.

Grillo, C.A. and F.N. Dulout. 1995. Cytogenetic Evaluation of Butylated Hydroxytoluene. Mutat. Res., (345) : 73-85.

Safer, A.M. dan A.L. Nughamish. 1999. Hepatotoxicity Induced by the Antioxidant Food Additive Butylated Hydroxytoluene (BHT) in Rats: An Electron Microscopical Study. Histol. Histopathol., XIV: 391-406.

Shanab, S.M.M.. 2007. Antioxidant and Antibiotic Activities of Some Seaweeds (Egyptian Isolates). Agriculture and Biology, IX (2): 220-225.

Oktay, M., I. Gulcin, and O., Kufrevioglu, 2003. Determination of In Vitro Antioxidant Activity of Fennel (Foeniculum Vulgare) Seed Extract. Lebensmittel-Wissenchaft and Technology, XXXVI: 263-271.

Richmond, A.E.. 1986. Microalga Culture. Tokyo: CRC Press.

Wulandari, A.P., Frida N., Annisa E.P., dan Dilaekha R.P.. 2010. Identifikasi Mikroalgae di Sekitar Pantai Pangandaran dan Potensi Pertumbuhannya pada Formulasi Medium Ekstrak Tauge (MET). Prosiding Seminar Nasional Limnologi, V.

Carolina, S. 1995. Kualitas Algae Bersel Tunggal Chlorella sp. pada Berbagai Media. Seminar Ilmiah. Balai Pengembangan Teknologi Tepat Guna, Puslitbang Fisika Terapan-LIPI, Subang.

Hidayati, Nurul. 2009. Uji Efektivitas Antibakteri Ekstrak Kasar Daun The (Camellia sinensis L, v. assamica) Tua Hasil Ekstraksi Menggunakan Pelarut Akuades dan Etanol. Skripsi Tidak Diterbitkan. Malang: Universitas Islam Negeri Maulana Malik Ibrahim Malang.

Prihantini, N.H, Putri B., dan Yuliati R.. 2005. Pertumbuhan Chlorella sp. dalam Medium Ekstrak Tauge (MET) dengan Variasi pH Awal. Makara, Sains, IX (1): 1-6.

Hanani, E., M. Abdul dan Ryany, S. 2005. Identifikasi Senyawa Antioksidan dalam Spons Callyspongia sp. dari Kepulauan 
Seribu. Majalah Ilmu Kefarmasian, II (3): 127-133.

Arindah, D. 2010. Fraksinasi dan Identifikasi Golongan Senyawa Antioksidan pada Daging Buah Pepino (Solonum Muricatum aiton) yang Berpotensi sebagai Antioksidan. Skripsi Tidak Diterbitkan. Malang: Jurusan Kimia Fakultas Sains dan Teknologi Universitas Islam Negeri (UIN) Maulana Malik Ibrahim Malang.

Persagi (Persatuan Ahli Gizi Indonesia). 2009. Tabel Komposisi Pangan Indonesia. Jakarta: PT. Elex Media Komputindo.

De La Noue dan De Pauw. 1988. The Potential of Microalgal Biotechnology : A Review of Production and Uses of Microalgae. Journal of Biotechnology Advances, VI.

Schlegel, S. 1994. Mikrobiologi Umum. Tedja Baskara, penerjemah. Yogyakarta: Gajahmada University Press.

Herbert RB. 1995. Biosintesis Metabolit Sekunder. Bambang Srigandono, penerjemah. Edisi kedua. Semarang: IKIP Semarang Press.
Yudha, A.P.. 2008. Senyawa Antibakteri dari Mikroalga Dunaliella $s p$. pada Umur Panen yang Berbeda. Skripsi Tidak Diterbitkan. Bogor : Fakultas Perikanan dan Ilmu Kelautan, Institut Pertanian Bogor.

Vonshak, A. 1990. Recent Advances in Microalgal Biotechnology. Biotechnology adv, VIII.

Sopyan, I. 2001. Rancangan Awal Alat Pengering Energi Matahari (Solar Dryer) untuk Pengeringan Rumput Laut. Skripsi Tidak Diterbitkan. Bogor: Institut Pertanian Bogor.

Brand-Williams, W. 1995. Use of Free Radical Method to Evaluate Antioxidant activity. Lebensmettel - Wissenschaft and Technologie. Dalam Ratmo. 2007. Potensi Ekstrak Daun Sirih Merah (Piper crocotum) sebagai Antioksidan. www.kimiabrawijaya.ac.id.

Josephy, P.D. 1997. Molecular Toxicology. New York: Oxford University Press.

Harborne, JB.. 1987. Metode fitokimia Edisi Kedua. Padmawinata K, Soediro I, penerjemah. Bandung: Institut Teknologi Bandung. 